\title{
Mississippi State University Engineering Entrepreneurship Program
}

\author{
Gerald Nelson \\ and \\ Robert P. Taylor \\ Mississippi State University \\ The James Worth Bagley \\ College of Engineering
}

\begin{abstract}
$\underline{\text { Abstract }}$
A successful engineering entrepreneurship program has been established in the James Worth Bagley College of Engineering at Mississippi State University. The program has three phases: a seminar series, a project experience with strong ties to entrepreneurial business, and a formal course of study leading to a certificate. Student interest has been excellent, with attendance at the seminars being as high as 160. Approximately 30 students are pursuing the certificate in the second year. The program has been endowed by an alumnus who established the Jack Hatcher Chair in Engineering Entrepreneurship. An advisory board of successful entrepreneurs is providing leadership for the program.
\end{abstract}

\section{Introduction}

The role of the engineering entrepreneur in the expansion of the economy is self-evident. Engineers with entrepreneurial sprit and skills are the locomotives of the technology-based startup company and, perhaps more importantly, of the evolution of established industry. Developing entrepreneurial thinking in our graduates is one of the primary learning goals of the Bagley College. Through an endowment by alumnus Jack Hatcher and the support of the Robert M. Hearin Foundation of Jackson, Mississippi, we have established a multilevel engineering entrepreneurship program to serve students with different degrees of interest. The base mission of the program is to expose our students to the broader elements of running a business and the general managerial skills required to prepare them for opportunities in management. For a more limited number, our mission is to equip technologically creative students to recognize opportunities and help instill the confidence to start entrepreneurial businesses. The vision of the Jack Hatcher Entrepreneurship Program is given in Figure 1.

The basic and broadest element of the entrepreneurship program is a weekly seminar series in which successful entrepreneurs present case histories. Also business leaders discuss specific items, such as patents, hiring employees, and venture capital. The next level is the Idea Fair and 
team projects. At the Idea Fair, select companies are invited to present ideas for products or services that may have commercial value. For those that generate significant student interest, interdisciplinary student teams are formed to develop the product or service. The participating companies provide materials, guidance, and encouragement. The projects also provide credit for design or technical elective classes. Students may also form teams around their own entrepreneurial ideas. A business plan competition is held each year with a small cash award.

Vision of the Jack Hatcher Engineering Entrepreneurship Program

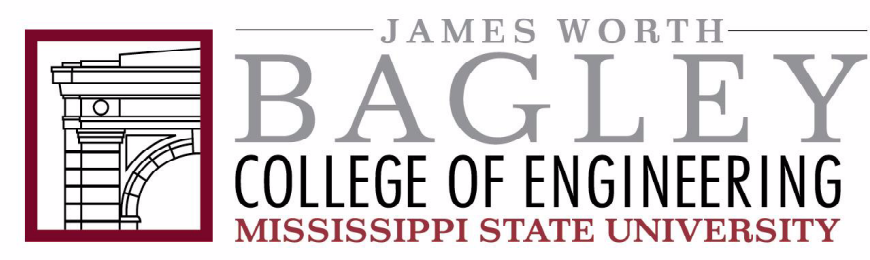

- The engineering student who is in business can receive the education and experience to pursue a technical/business career.

- The entrepreneurship program provides a forum for learning and experiencing business firsthand from professionals

- The certificate process builds teamwork and communication skills in interdisciplinary project teams

- The student who desires to launch a business is provided with foundational knowledge, experience, and mentoring.

- The student who decides to pursue an engineering or management career goes into the work place with working knowledge of business and as a more valuable employee

- Mississippi and the surrounding states enjoy a higher level of economic development.

Figure 1. Vision of the Jack Hatcher Engineering Entrepreneurship Program.

For students with higher levels of interest, a formal course of study leading to an Entrepreneurship Certificate is available. The certificate program requires a minimum of 15 semester hours. Students gain knowledge in finance, marketing, and accounting followed by a management course in entrepreneurship where the capstone project is a business plan.

The following elements are discussed in detail below: the seminar series, the "company experience and the Idea Fair, the Certificate, and the leadership of the program.

\section{The Seminar Series}

The Seminar Series is a weekly event that interested students can attend on an ad hoc basis or can take for one hour of class credit. Credit enrollment is currently about 40 students. Weekly attendance is typically 100 students. This is the broadest base of the Jack Hatcher Entrepreneurship Program. The objectives of the Seminar Series are

- Through the examples of the case studies, give the students insight into the process of recognition of opportunity.

- Provide basic knowledge of the underlying business skills required to start and run a

Proceedings of the 2003 American Society for Engineering Education Annual Conference \& Exposition Copyright 2003, American Society for Engineering 
business.

- And, through the life stories of successful entrepreneurs, build students' self confidence to take advantages of opportunities

A typical day for a seminar speaker begins with lunch with the Dean of Engineering and selected students with a keen interest in the entrepreneurship program. The seminar is presented in the afternoon and includes an introduction and biographical sketch of the speaker. Usually a formal presentation is given; however, sometimes a less formal panel discussion format is used. Following the presentation, students can visit with the speaker to ask more individual questions.

The grades for students taking the seminar for credit are based on attendance and written reviews of seminar sessions.

Speakers are selected to represent a variety of backgrounds. Some have started companies that have grown into major industries. Others have started and operated companies with fewer than 100 employees. A number of the speakers have professional backgrounds in business and give lectures on specific topics such as venture capital. The speaker list for the Fall Semester of 2002 is

\author{
Barrie McArthur \\ President and Founder, Diversified Technology \\ A specialty computer design and manufacturing company
}

Kelly Williams

Greenover Managers, LLC

A venture capital company

Rodger Johnson

President of Knology, Inc

A telecommunication and digital cable TV company

Charles Warner

Troutman Sanders

A patent law firm

Danny Windham

Senior Vice President and General Manager of ADTRAN

A telecommunications equipment manufacturer

Tony Skjellum

Founder and President of MPI, Inc.

A software development company

Mark Rodgers

Founder and President of SmartSynch 
A provider of smart metering systems for the electric power industry

\author{
James Worth Bagley \\ Chief Executive Officer of Lam Research
}

A supplier of wafer fabrication equipment for the semiconductor industry

Les Lampton

Founder and President of Ergon, Inc.

A diversified manufacturing and transportation company

Student interest has been very high, often exceeding 100 students.

The "Company" Experience and the Idea Fair

The company experience is a real-world experience developing a marketable engineered product or engineering service. The objective is to allow student teams to enhance their required engineering design projects by adding the extra dimension of developing a product or service for the market. This allows a student interested in entrepreneurship to practice his or her entrepreneurial and business skills while completing a technical requirement of the curriculum.

One of the more significant problems that students have with this process is coming up with ideas for a company project. In order to help students, we have developed the Idea Fair.

Companies and individuals are invited to present technology ideas that they have not developed but have great potential as marketable products or services. The first Idea Fair was held on February 21, 2001. The eight companies featured were Lextron, Viking Range, ADTRAN, Diversified Technology, Wireless Land, Severne Trent Environmental Services, New Orleans Physicians' Group, and Silicon Metrics. Idea fairs have been held in each semester since. For Fall 2002, companies included Diversified Technology, ADTRAN, SmartSynch, Synapse, MFJ Enterprises, Viking Range, Skytel, and HMC Technologies. In addition, two ideas were presented by individuals.

More than 120 students gathered in the Eastman Auditorium of Swalm Hall to hear quick five-minute overviews of the ideas. After the general session, particular companies went into breakout sessions to discuss the ideas in more depth. Each idea attracted a number of students. Example projects are those with Viking Range, New Orleans Physicians' Group, and ADTRAN.

Viking is a manufacturer of high-end kitchen appliances. They pioneered the commercialgrade cooking range for the home kitchen. Viking has recently acquired the Amana line of appliances and is expanding its product base. Viking challenged the teams to develop new ways to clean dishes. A three-member electrical team, Michael Nestler, Naquisha Causey, and Rockell Ingram, and a six-member mechanical team, Brian Snowden, Jason Lea, Justin Crapps, Justin Goldman, Matthew LeCren, and Matthew Jennings, have formed around the Viking dishwasher idea. The electrical team is focusing on the controls, electronics, and user interface, while the mechanical team is focusing on the hydro-mechanical processes. 
A six-member team of biomedical engineering students has formed around a project proposed by Physicians' Group. Each year in the United States, three to four children are killed while playing baseball, softball, or ice hockey. The reason is Commotio Cordis, which is a stoppage of the heart caused by blunt blow to the chest. The team is developing a chest protector to help reduce the risk of this condition. The members of the team are Betsy Mann, Kristi Holland, Mark Marini, Misti Marr, Ryan Kelley, and Shannon Maloy.

ADTRAN is a manufacturer of telecommunications equipment. They presented the idea of developing a diagnostic instrument around the hand-held personal digital assistant. Currently testing is conducted in situ on equipment using a laptop computer. A PDA would be much more convenient. Two teams have developed around this idea. A software team, Dave Richards, Ed Carpenter, Joe Thompson, Kenneth Fagel, Kyle Conway, Lee Hathcock, and Wesley McGraw, is developing the application software. A hardware team, Peter Trenkel, Stephen Porter, Shawn McFarland, and Hui-Yang Sim is developing an infrared communications interface to enable the PDA to communicate with the equipment being tested.

In addition to ideas that come from companies, student concepts are encouraged. Jon Cavin and Paul McCarley from Mechanical Engineering and Susan Robertson from the College of Business formed a team to develop a concept for a variable backpressure automobile exhaust system. The system automatically tunes the exhaust backpressure for maximum performance through out the full range of engine speeds. This team won first place in the Fall 2002 business plan competition.

\section{$\underline{\text { The Certificate Program }}$}

The Jack Hatcher Entrepreneurship Certificate is a formal course of study designed for engineering students planning to pursue a career combining technical and business skills. This could include a business startup or working for an entrepreneur in the early years of the business. The certificate also enhances the engineering program for students interested in corporate management. An entrepreneurial education and the spirit of entrepreneurship send a message that this is an engineer trained to go beyond the technical arena. The certificate program is a joint undertaking between the Colleges and Engineering and Business and Industry.

All undergraduate engineering and computer science students in good standing are eligible to join the program. Each student must have a faculty mentor from both engineering and business and industry. To join the program, a student must submit an application to the Associate Dean of Engineering that has been signed by both mentors.

The Entrepreneurship Certificate Program is comprised of three major parts:

1. Completing 15 hours of business and engineering classes:

- ACC 1203 Basic Industrial Accounting

- EC 2123 Microeconomics

- IE 3913 Engineering Economy

- MKT 3323 Principles of Marketing

- MGT 3323 Entrepreneurship

Proceedings of the 2003 American Society for Engineering Education Annual

Conference \& Exposition Copyright 2003, American Society for Engineering

Education 
2. The Seminar Series - GE 3011.

3. The "company" or project experience.

By utilizing electives, students in most engineering disciplines can complete the course requirements with a maximum of six to nine hours of additional work above the degree program. Also, much of the coursework will apply toward the prerequisites for an MBA degree at a later time should the student decide to pursue that path.

A GPA of 2.25 is required on all coursework, and no grade less than a C can be applied toward the certificate. A maximum of two courses can be transfer courses, and correspondence courses will not be accepted. In addition, a passing grade must be obtained for three semesters of GE 3011—Engineering Entrepreneurship Seminar.

The "company" or project experience is the real-world engineering experience of developing a marketable product or service previously described. In most cases, the certificate candidate can get academic credit through the senior design course or a technical elective. For example, Electrical Engineering and Computer Engineering majors can get credit for the senior design project requirement (ECE 4512/4522 and ECE 4521). The "company" experience may be a project proposed by one of the participating companies in the Idea Fair or a concept developed by students or faculty members. To complete the requirements for the project experience, the candidate submits a report to the Associate Dean, which has been approved by both mentors. This report usually takes the form of a Business Plan and is developed as part of the entrepreneurship course MGT 3323.

Upon completion of the Entrepreneurship Certificate Program requirements, the Associate Dean will review the student's records. If all requirements are met satisfactorily, the Associate Dean will submit the candidate to the Deans of Business and Industry and of Engineering for issuance of the certificate. The Associate Dean will notify the Registrar to have a statement placed on the candidate's transcript. The certificate will be issued concurrently with the B.S. degree in Engineering or Computer Science.

About 30 students are currently pursuing the Entrepreneurship Certificate. The first certificates were issued in December 2002.

\section{Leadership}

The Jack Hatcher Entrepreneurship Chair in Engineering Entrepreneurship has been endowed to provide leadership for the program. Currently, Mr. Gerald Nelson, a recognized entrepreneur is coordinating the program. His experience, network of contacts, and commitment have enabled the Entrepreneurship Program to develop rapidly.

The Jack Hatcher Chair will be expected to:

- Lead efforts to bring top entrepreneurs as speakers/mentors,

Proceedings of the 2003 American Society for Engineering Education Annual Conference \& Exposition Copyright 2003, American Society for Engineering 
- Develop partnerships with startups, technology companies, and other organizations which further our mission, and

- Provide high-profile representation at national symposia and strategically important meetings

Guidance for the program is also provided by an advisory board. The current membership of the Entrepreneurship Advisory Board is

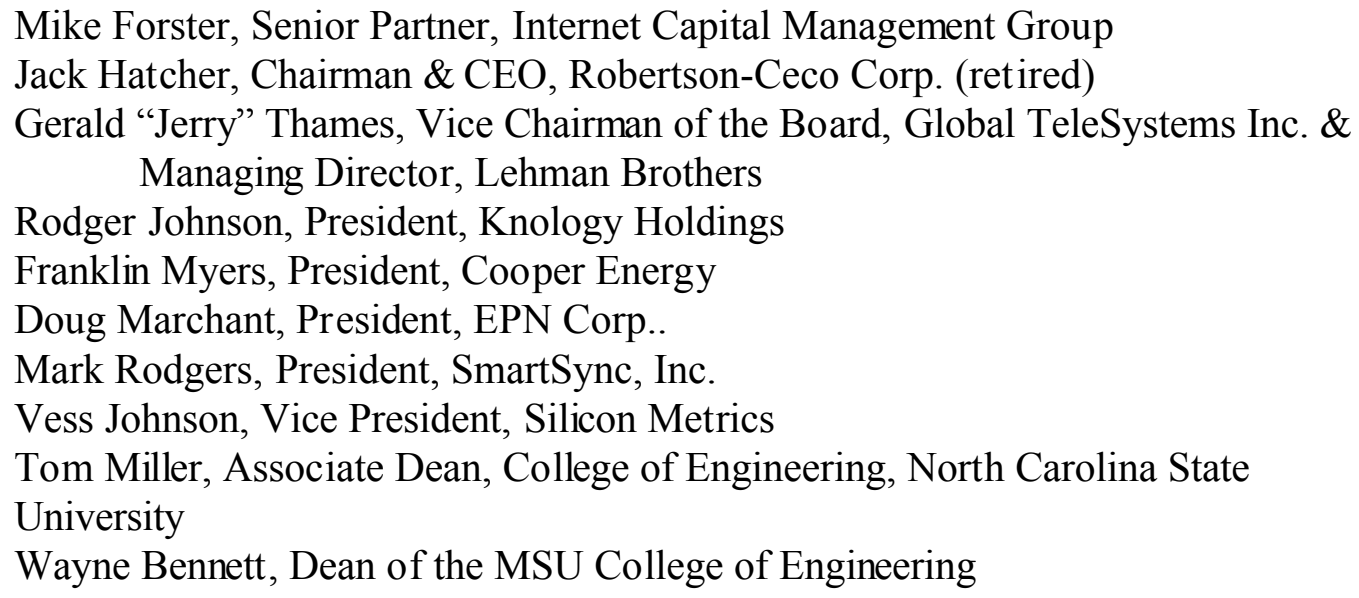

The Entrepreneurship Advisory Board leads by:

- Meeting quarterly to review Program status and recommend changes and enhancements,

- Aiding the Chair in bringing new speakers/mentors to campus,

- Aiding the Chair in creating business partnerships vital to our mission, and

- Serving as champions for the Program when asked by the Chair

\section{Biographical Information}

Gerald Nelson is the Director of the Entrepreneurship Program. He holds a B.S.I.E. and M.B.A. from Mississippi State University. Previous Industry Experience includes C.O.O. at Deka Medical, Inc. and E.V.P. of Operations at Viasyatems Group, Inc.

Robert P. Taylor is Associate Dean of Engineering and Professor of Mechanical Engineering at Mississippi State University. He has a B.S.M.E. from Mississippi State University, an M.S.M.E. from Purdue University, and a Ph.D. in Mechanical Engineering from Mississippi State University. 